\title{
Efisiensi Penyisihan Kadar Amoniak Limbah Cair Rumah Sakit dengan Proses Adsorpsi Karbon Aktif Bijih Plastik
}

\author{
Tati Ruhmawati $^{*}$, Teguh Budiasyah ${ }^{2}$ dan Ridwan Setiawan ${ }^{1}$ \\ ${ }^{1}$ Jurusan Promosi Kesehatan Poltekkes Kemenkes Bandung, Kota Bandung, Jawa Barat 40171 \\ ${ }^{2}$ Jurusan Kesehatan Lingkungan Poltekkes Kemenkes Bandung, Kota Cimahi, Jawa Barat 40514 \\ *Corresponding author: muslimah_tati@yahoo.com \\ Info Artikel : Diterima 6 November 2019 ; Disetujui 21 April 2020 ; Publikasi 1 Oktober 2020
}

Cara Sitasi (Vancouver): Ruhmawati T, Budiasyah T, Setiawan R. Efisiensi Penyisihan Kadar Amoniak Limbah Cair Rumah Sakit dengan Proses Adsorpsi Karbon Aktif Bijih Plastik. Jurnal Kesehatan Lingkungan Indonesia [Online 2020 Oct;19(2):82-88. https://doi.org/10.14710/jkli.19.2.82-88.

\begin{abstract}
ABSTRAK
Latar belakang: Tingginya kunjungan pasien akan meningkatkan kandungan amoniak limbah cair rumah sakit.Kadar amoniak yang tinggi menimbulkan pencemaran perairan. Adsorpsi karbon aktif merupakan teknologi alternatif dalam menurunkan kadar amoniak limbah cair.Tujuan penelitian ingin mengetahui pengaruh variasi waktu kontak karbon aktif bijih plastik terhadap penurunan kadar amoniak limbah cair rumah sakit.

Metode: Jenis penelitian eksperimen dengan rancangan pretest-postest dengan kontrol. Populasi, seluruh air limbah yang diambil dari influent RSUD Al Ihsan Kabupaten Bandung, sedangkan sampel sebagian air limbah yang diambil dari populasi dengan teknik pengambilan gabungan waktu.Data yang telah terkumpul dianalisis menggunakan uji anova.

Hasil: Hasil penelitian menunjukkan rata-rata persentase penurunan kadar amoniak untuk waktu kontak 60 menit 18,40\%, 90 menit35,07 \%, dan 120 menit 48,77\%. Hasil uji Anova diperoleh nilai p 0,001 lebih kecil dari $0,05(\alpha 5 \%)$.

Simpulan:Terdapat pengaruh yang bermakna antara variasi waktu kontak karbon aktif bijih plastik terhadap penurunan kadar amoniak limbah cair.
\end{abstract}

Kata Kunci: Amoniak; Limbah Cair; Adsorpsi; Bijih Plastik

\section{ABSTRACT}

Title: Elimination Efficiency of Ammonia Content of Hospital Liquid Waste with Active Carbon Plastic Ore Adsorption.

Background: Considerable visits from patients increases the content of ammonia within the liquid waste of the hospital which, in turn, results in water pollution. Adsorption of active carbon is an alternative technology in reducing the ammonia level of liquid waste. This research aims at revealing the contact time of active carbon plastic ore towards the degression of ammonia level of liquid waste.

Method: This research was an experiment designed by pretest-posttest design with control. The population of the research was all the liquid waste taken from the influent of RSUD Al Ihsan Bandung, while the sample of the research was taken from the population by time combiningcollection technique. The collected data was then analyzed using anova.

Result: The results of the research show that the average of the degression percentage for contact time of sixty minutes is $18.40 \%$, 90 minutes $35.07 \%$, and 120 minutes $48.77 \%$. The value of t acquired from anova testing is 0.001 , smaller than degression of ammonia level of liquid waste.

Conclusion: There is a significant effect between the variation of contact time of plastic ore activated carbon to the decrease in the level of liquid waste ammonia. 
Keywords: Ammonia; Liquid Waste; Adsorptio; Plastic Ores

\section{PENDAHULUAN}

Rumah sakit merupakan tempat pelayanan kesehatan masyarakat dengan jam operasional yang tinggi dan beroperasi setiap hari. Rumah Sakit Umum Daerah Al-Ihsan Kabupaten Bandung melayani rawat jalan dan rawat inap yang cukup padat aktivitasnya dengan persentase peningkatan kunjungan rawat jalan pada tahun 2014 sebesar 79,33\% dan meningkat menjadi $87,33 \%$ pada tahun 2015. Debit limbah cair di RSUD Al Ihsan Provinsi Jawa Barat sebesar 29.19 $\mathrm{m}^{3}$ /hari dengan jumlah tempat tidur 294. Banyaknya pasien yang berobat maupun keluarga pasien yang menginap akan meningkatkan kadar amoniak limbah cair rumah sakit. Air kencing (urin) menjadi penyumbang kadar amoniak yang tinggi. Dengan semakin meningkatnya pelayanan kesehatan secara langsung maka akan mengakibatkan semakin meningkatkan potensi pencemaran lingkungan, karena limbah yang dihasilkan akan semakin banyak. Apabila limbah cair rumah sakit tersebut tidak diolah dengan baik, akan menimbulkan dampak terhadap lingkungan dan manusia. Dampak yang ditimbulkan jika kadar amoniak tinggi keberadaannya pada perairan akan menyebabkan biota-biota perairan tersebut mati, sedangkan efek yang timbul pada manusia akan menyebabkan iritasi pada saluran pernafasan dan mata, bahkan sampai mengakibatkan kematian. Konsentrasi $1 \mathrm{mg} \mathrm{NH} 3 /$ liter, dapat menyebabkan beberapa jenis ikan mati lemas karena amonia dapat mengurangi konsentrasi oksigen dalam air. ${ }^{1}$ Amoniak juga mudah larut dalam air, menaikkan $\mathrm{pH}$ air menjadi basa, sehingga air menjadi tercemar. ${ }^{2}$ Rumah sakit memiliki kewajiban untuk mengelola limbah cair yang dihasilkan agar memenuhi standar baku mutu dan aman bagi lingkungan.Untuk itu diperlukan teknologi alternatif yang dapat menurunkan kadar amoniak limbah cair rumah sakit, salah satunya adalah proses adsorpsi menggunakan karbon aktif. Karbon aktif adalah adsorben yang sangat serbaguna karena ukuran dan distribusi pori-pori dalam matriks karbon dapat dikendalikan. ${ }^{3}$ Salah satu karbon aktif yang dapat digunakan adalah karbon aktif yang berbahan baku sampah plastik (LDPE) yang dijadikan bijih plastik.

Sampah menduduki peran penting dalam masalah pencemaran lingkungan baik di kota-kota besar maupun di desa. Dalam kehidupan sehari-hari hampir semua orang menggunakan plastik, seperti kantong, sedotan, bungkus makanan dan masih banyak lagi plastik sejenisnya yang kemudian berakhir menjadi sampah. Akibatnya jutaan sampah plastik mencemari lingkungan. ${ }^{4}$ Tingginya pola konsumsi juga telah menyumbang semakin menumpuknya timbulan sampah, beberapa parameter yang dapat menyebabkan semakin tingginya masalah sampah adalah pertumbuhan penduduk, pertumbuhan ekonomi, pola konsumsi dan sosial masyarakat serta kepadatan penduduk. Sampah yang tidak dikelola dengan baik akan menjadi sarana penularan penyakit serta menjadi tempat berkembangbiak vektor penular penyakit. ${ }^{5}$ Peningkatan jumlah penduduk dan gaya hidup sangat berpengaruh pada volume sampah yang dihasilkan. Produksi sampah plastik di Indonesia sangat besar sebab secara total produksi sampah Indonesia mencapai 189 kilo ton/hari jauh lebih besar dibandingkan dengan negara-negara di Asia Tenggara. Hal ini disebabkan jumlah penduduk Indonesia yang lebih besar dibandingkan dengan jumlah penduduk negara-negra di Asia Tenggara. ${ }^{6}$ Komposisi sampah yang dihasilkan dari aktivitas manusia adalah sampah organik sebanyak $60-70 \%$, sisanya $(30-40 \%)$ adalah sampah non organik, komposisi sampah non organik $14 \%$ berupa sampah plastik. Jenis sampah plastik yang terbanyak adalah kantong plastik. Permasalahan sampah plastik tersebut apabila semakin banyak jumlahnya di lingkungan maka akan berpotensi mencemari lingkungan. Jumlah limbah plastik akan terus bertambah, disebabkan sifat-sifat yang dimiliki plastik, antara lain tidak dapat membusuk, tidak terurai secara alami, tidak dapat menyerap air, maupun tidak berkarat, dan pada akhirnya menjadi masalah bagi lingkungan. ${ }^{7}$ Mengingat bahwa sifat plastik sulit terurai sehingga dapat menurunkan kesuburan tanah dan mencemari perairan. Oleh karena itu sampah plastik harus dimanfaatkan.Sampah plastik jenis polyethylene dapat didaur ulang kembali sebagai bahan pembuat karbon aktif untuk proses adsorpsi dalam pengolahan limbah cair. ${ }^{8}$ Sampah plastik berbahan baku polietilene tereftalat dapat dijadikan karbon aktif untuk pengolahan limbah cair kain jumputan. ${ }^{9}$ Karbon aktif bijih plastik mengandung senyawa karbon (C) dan nitrogen (N), senyawa tersebut dapat mereduksi bahan-bahan organik seperti, polycyclic aromatic hydrocarbons, aromatic hydrocarbons, aldehydes dan lainnya. ${ }^{10}$ Karbon aktif dari bijih plastik (LDPE) ini cocok sebagai media adsorpsi karena pada setiap tulang punggung polimernya terdapat 1000 senyawa karbon. ${ }^{11}$

Prinsip kerja karbon aktif dalam mereduksi limbah amoniak adalah terjerapnya (pelekatan) suatu zat (molekul atau ion) pada permukaan adsorben melalui proses adsorpsi. Tingkat adsorpsi umumnya meningkat seiring dengan menurunnya suhu. Waktu kontak merupakan hal yang menentukan dalam proses adsorpsi. Gaya adsorpsi molekul dari suatu zat terlarut akan meningkat apabila waktu kontak dengan karbon aktif semakin lama. Waktu kontak yang lama memungkinkan proses difusi dan penempelan molekul zat terlarut yang teradsorpsi berlangsung lebih baik. ${ }^{12}$

Kajian penanganan amoniak pada limbah cair menggunakan karbon aktif sudah banyak dilakukan. Hasil penelitian lain menggunakan karbon aktif berbentuk granul dan filter zeolite dapat menurunkan 
COD sebesar 59,46\%, amoniak $60,82 \%$, dan warna $58,4 \% .{ }^{13}$ Penelitian menggunakan karbon aktif bijih plastik dengan berat bijih plastik 3 gram mampu menurunkan kadar phosphat 45,45\%. ${ }^{14}$ Banyaknya penelitian yang telah dilakukan berkaitan dengan karbon aktif bijih plastik, menunjukkan bahwa karbon aktif bijih plastik mampu mengolah limbah cair. Penelitian ini merupakan penelitian lanjutan,tujuan penelitian untuk mengetahui efisiensi penyisihan kadar amoniak setelah proses adsorpsi menggunakan karbon aktif bijih plastik serta pengaruh variasi waktu kontak terhadap penurunan kadar amoniak limbah cair rumah sakit. Perbedaan penelitian ini dengan penelitian yang sudah dilakukan adalah variasi waktu kontak yang digunakan.

\section{MATERI DAN METODE}

Jenis penelitian yang dilakukan termasuk penelitian eksperimen (skala laboratorium) dengan rancangan pretest-postest dengan kontrol. Rancangan penelitian ini mengelompokkan anggota kontrol dan kelompok perlakuan yang dilakukan secara acak, adanya penelitian pendahuluan (pretest) pada kelompok kontrol dan kelompok perlakuan diikuti dengan intervensi pada kelompok perlakuan dan dilakukan postest setelah perlakuan. Intervensi dilakukan dengan cara mengontakkan karbon aktif bijih plastik pada limbah cair rumah sakit yang akan diolah/diturunkan kadar amoniaknya. Tujuan penelitian adalah untuk mengetahui pengaruh berbagai lama waktu kontak proses adsorpsi menggunakan karbon aktif bijih plastik terhadap penurunan kadar amoniak limbah cair rumah sakit serta berapa besar efisiensi penyisihan kadar amoniak setelah proses adsorpsi menggunakan karbon aktif bijih plastik. Populasi sampel adalah seluruh air limbah yang diambil dari limbah cair RSUD Al Ihsan Kabupaten Bandung, sedangkan sampel sebagian air limbah yang diambil dari populasi dengan teknik pengambilan sampel gabungan waktu. Penelitian ini menggunakan rancangan acak lengkap (RAL) karena bahan percobaan dianggap homogen. Banyaknya pengulangan (replikasi) dalam penelitian ini ditentukan berdasarkan banyaknya perlakuan yang dilakukan. Ada tiga perlakuan dengan waktu kontak selama 60 menit, 90 menit, dan 120 menit. Dengan menggunakan RAL maka jumlah pengulangan adalah enam kali.

Karbon aktif bijih plastik yang digunakan dalam penelitian ini adalah bijih plastik yang terbuat dari kantong plastik jenis Low-density polyethylene plastics (LDPE). Pembuatan bijih plastik dilakukan dengan cara sebagai berikut :

a. Mencuci kantong plastik dengan air yang mengalir,

b. Memotong plastik menjadi bagian kecil,

c. Menjemur potongan plastik di bawah sinar matahari sampai potongan plastik kering, d. Memasukkan potongan plastik ke dalam carbonasi furnace, lalu menyalakan pemantik api untuk melakukan proses thermal dari alat tersebut,

e. Menampung cairan karbon ke dalam ember yang berisi air untuk proses pembekuan karbon,

f. Memotong karbon yang sudah membeku sepanjang $1 \mathrm{~cm}$,

g. Melalukan proses aktivasi dengan merendam bijih plasik yang dihasilkan menggunakan larutan aceton selama 24 jam. Kemudian keringkan di udara terbuka dan di panaskan dengan cahaya matahari.

h. Merendam karbon aktif bijih plastik menggunakan HCL 1 M selama 2 jam, kemudian keringkan di udara terbuka dan dipanaskan dengan cahaya matahari.

Bijih plastik yang dihasilkan selanjutnya dimasukkan ke dalam tabung percobaan untuk dikontakkan dengan limbah cair rumah sakit. Karakteristik awal limbah cair rumah sakit meliputi kadar amoniak adalah 41,90 mg/L, nilai $\mathrm{pH}$ sebesar 9,25 dan temperatur sebesar $25^{\circ} \mathrm{C}$. Secara rinci cara kerja penelitian adalah sebagai berikut :

a. Mengisi tabung percobaan dengan limbah cair rumah sakit untuk dikontakkan dengan karbon aktif bijih plastik. Limbah cair dikontakkan dengan karbon aktif bijih plastik selama 60 menit, 90 menit, dan 120 menit.

b. Mengambil sampel limbah cair rumah sakit sebelum dan setelah dikontakkan dengan karbon aktif bijih plastik selama 60 menit, 90 menit, dan 120 menit, serta kontrol,

c. Memeriksa kadar amoniak, $\mathrm{pH}$ dan temperatur sampel limbah cair rumah sakit sebelum dikontakkan dengan karbon aktif bijih plastik,

d. Memeriksa kadar amoniak, $\mathrm{pH}$ dan temperatur sampel limbah cair rumah sakit setelah dikontakkan dengan karbon aktif bijih plastik,

e. Memeriksa kadar amoniak, $\mathrm{pH}$ dan temperatur pada kontrol,

f. Karbon aktif bijih besi setelah digunakan dalam penelitian bisa diaktivasi kembali dengan cara merendam menggunakan larutan aceton selama 24 jam. 


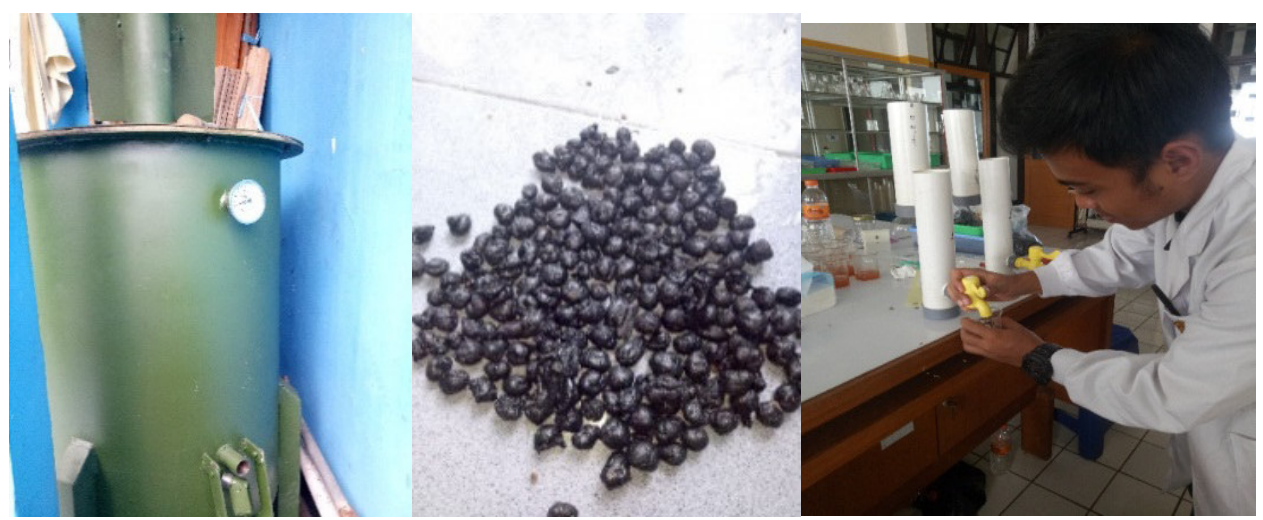

Gambar 1 Reaktor pembuat bijih plastik, karbon aktif bijih plastik, dan tabung percobaan

Data hasil pengukuran dan pemeriksaan selanjutnya diolah dan dianalisis univariat untuk melihat rata-rata kadar amoniak sebelum dan sesudah kontak dengan karbon aktif bijih plastik, serta persentase penurunan kadar amoniak setelah kontak dengan karbon aktif bijih plastik. Selanjutnya dilakukan analisis bivariat dengan menggunakan uji Anova.

\section{HASIL DAN PEMBAHASAN}

Berdasarkan hasil pemeriksaan, kadar amoniak pada air baku (kadar awal), amoniak pada kontrol, serta amoniak limbah cair rumah sakit setelah kontak dengan karbon aktif bijih plastik, dapat dilihat pada gambar 2.
Berdasarkan gambar 2 dapat dilihat ada perbedaan kadar amoniak setelah limbah cair rumah sakit dikontakkan dengan variasi waktu kontak yang berbeda. Kadar amoniak untuk waktu kontak 60 menit berkisar antara $31.14 \mathrm{mg} / \mathrm{L}-35.19 \mathrm{mg} / \mathrm{L}$, untuk waktu kontak 90 menit berkisar antara $24.25 \mathrm{mg} / \mathrm{L}-28.63$ $\mathrm{mg} / \mathrm{L}$, dan untuk waktu kontak 120 menit berkisar antara $19.67 \mathrm{mg} / \mathrm{L}-22.18 \mathrm{mg} / \mathrm{L}$. Menurut Peraturan Menteri Lingkungan Hidup Republik Indonesia Nomor 5 tahun 2014 tentang Baku Mutu Air Limbah, kadar amoniak bagi usaha dan/atau fasilitas pelayanan kesehatan adalah sebesar $10 \mathrm{mg} / \mathrm{L}$.

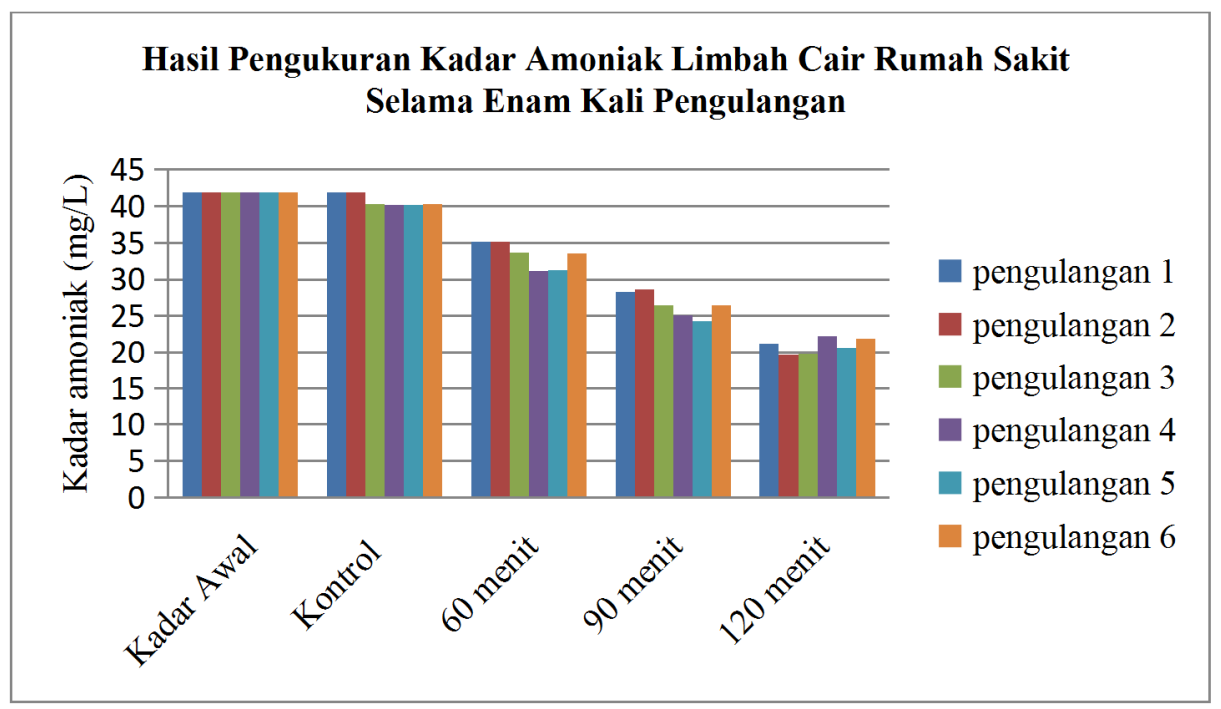

Gambar 2 Kadar Amoniak pada Air Baku (kadar awal), Kontrol dan Setelah Perlakuan 


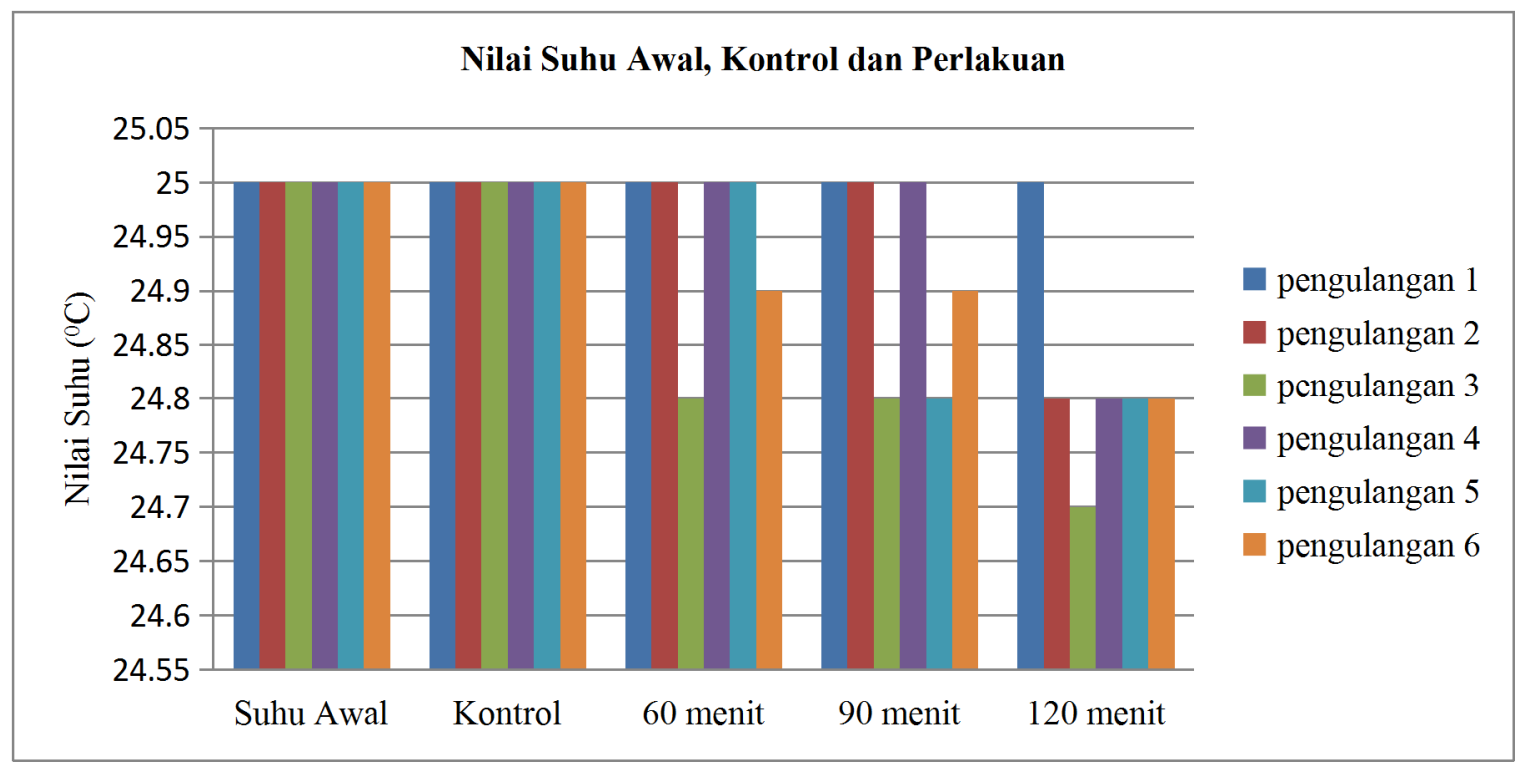

Gambar 3 Nilai Suhu pada Air Baku (suhu awal), Kontrol dan Setelah Perlakuan

Berdasarkan gambar 3 dapat dilihat nilai suhu awal limbah cair rumah sakit sebelum dikontakkan dengan karbon aktif bijih plastik dan pada kontrol sama yaitu $25^{\circ} \mathrm{C}$. Tidak terdapat perbedaan nilai suhu setelah kontak dengan karbon aktif bijih plastik, untuk waktu kontak 60 menit dan 90 menit $24,8{ }^{\circ} \mathrm{C}-25{ }^{\circ} \mathrm{C}$, sedangkan untuk waktu kontak 120 menit berkisar antara $24,7^{\circ} \mathrm{C}-25^{\circ} \mathrm{C}$. Untuk senyawa volatile, adsorpsi dilakukan pada temperatur kamar atau bila memungkinkan pada temperatur yang lebih rendah. ${ }^{15}$

Nilai $\mathrm{pH}$ awal limbah cair rumah sakit sebelum dikontakkan dengan karbon aktif bijih plastik dan pada kontrol sama yaitu 9,25, sedangkan nilai suhu pada kontrol berkisar antara 9,15 - 9,25. Ada perbedaan nilai $\mathrm{pH}$ setelah kontak dengan karbon aktif bijih plastik, untuk waktu kontak 60 menit berkisar antara 9,10- 9,12, untuk waktu kontak 90 menit berkisar antara 9,05 - 9,08, sedangkan untuk waktu kontak 120 menit berkisar antara 9,02 - 9,04. Jika sifat senyawa asam maka proses adsorpsi akan berjalan maksimal pada $\mathrm{pH}$ asamnya, sebaliknya jika sifat serapan basa, maka proses adsorpsi akan berjalan maksimal pada $\mathrm{pH}$ basa. ${ }^{15}$ Data nilai $\mathrm{pH}$ dapat dilihat pada gambar 4, dan Efisiensi penyisihan kadar amoniak pada limbah cair setelah kontak dengan karbon aktif bijih besi diperlihatkan pada gambar 5

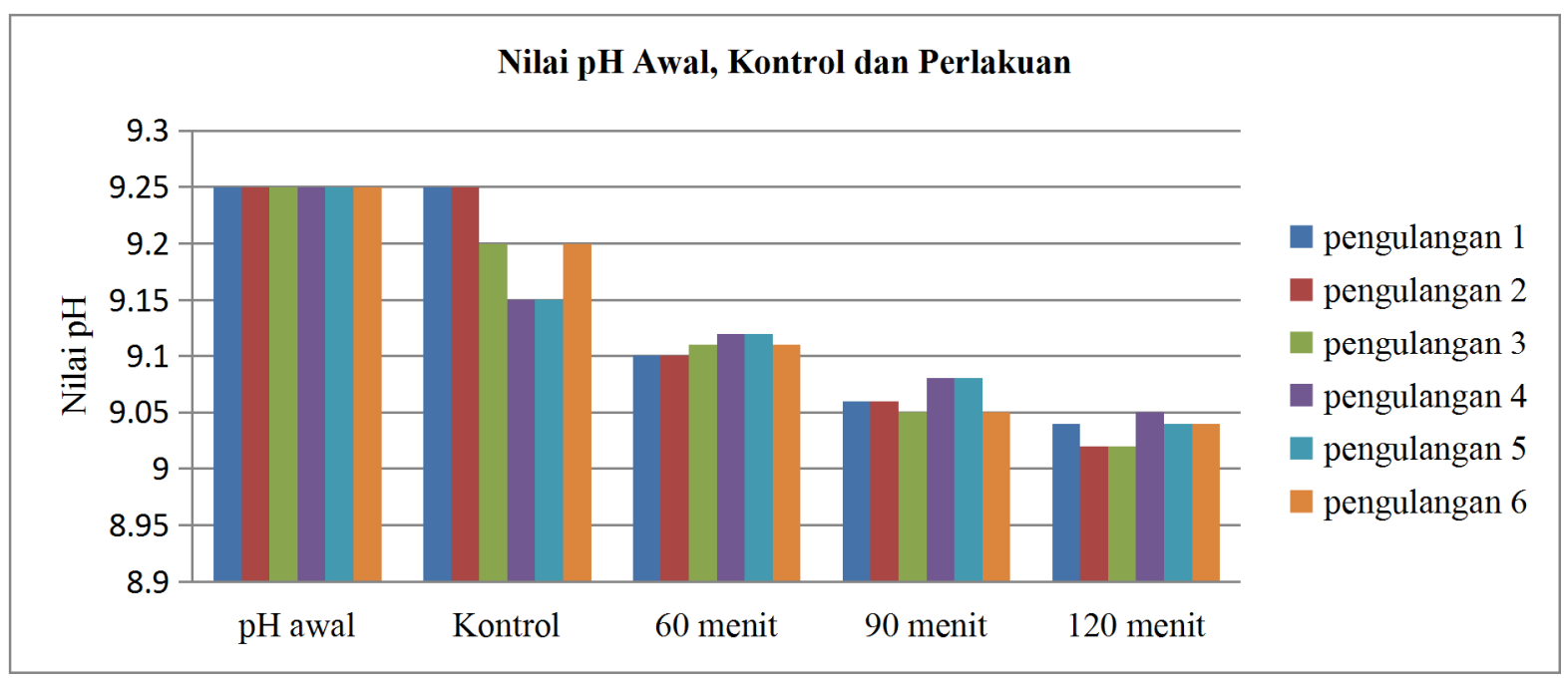

Gambar 4 Nilai pH pada Air Baku (pH awal), Kontrol dan Setelah Perlakuan 


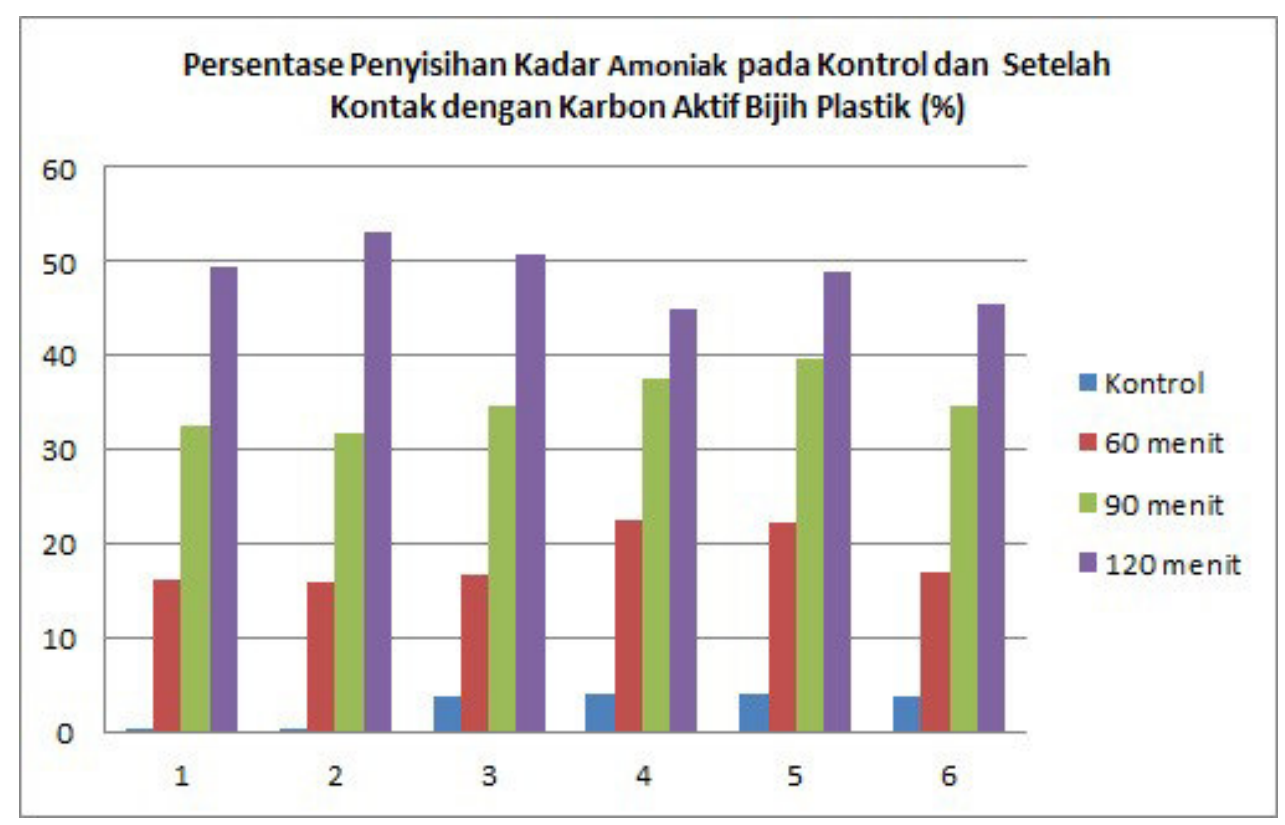

Gambar 5 Persentase Penyisihan Kadar Amoniak pada Kontrol dan Setelah Perlakuan

Berdasarkan gambar 5 dapat dilihat rata-rata persentase penurunan kadar amoniak pada kontrol $2,6 \%$, setelah kontak dengan karbon aktif bijih plastik selama 60 menit adalah sebesar $18,40 \%$, waktu kontak 90 menit penurunan kadar amoniak sebesar 35,07\%, dan waktu kontak 120 menit penurunan kadar amoniak sebesar 48,77 \%. Melihat data hasil penelitian semakin lama waktu kontak, penurunan kadar amoniak semakin besar. Terjadi penurunan kadar amoniak pada kontrol, tetapi sangat kecil sehingga pengaruhnya tidak signifikan. Hasil analisis statistik diperoleh nilai $\mathrm{p}$ ( $p$-value) sebesar 0,001 lebih kecil dari $0,05(\alpha$ 5\%). Dengan demikian terdapat pengaruh yang bermakna antara variasi waktu kontak karbon aktif bijih plastik terhadap penurunan kadar amoniak limbah cair rumah sakit. Hal ini membuktikan bahwa karbon aktif bijih plastik mempunyai kemampuan untuk menurunkan kadar amoniak dan sangat bermanfaat dalam proses pengolahan limbah cair khususnya limbah cair rumah sakit. Karbon aktif bijih plastik dapat menurunkan kadar amoniak karena mengandung senyawa karbon sebagai senyawa utamanya. Terdapat fenomena adsorpsi yaitu terjadi gaya tarik-menarik antara substansi terserap (senyawa amoniak) dan substansi penyerapnya (karbon aktif bijih plastik). Pada proses adsorpsi, molekul adsorbat bergerak melalui bulk fasa gas menuju padatan dan berdifusi pada permukaan pori padatan adsorben melalui gaya van der waals sehingga, amoniak terserap kedalam pori-pori karbon aktif bijih plastik, maka terjadilah pengurangan atau penurunan kandungan amoniak pada limbah cair rumah sakit. ${ }^{16}$

Adsorpsi adalah proses perpindahan massa pada permukaan pori-pori dalam butiran adsorben. Perpindahan massa yang terjadi melalui batas antara dua fasa yaitu; gas-padat, cair-padat. Adsorpsi terjadi melalui proses; perpindahan massa dari cairan ke permukaan butir, difusi dari permukaan butir ke dalam butir melalui pori, perpindahan massa dari cairan dalam pori ke dinding pori, adsorpsi pada dinding pori.Adsorpsi dapat terjadi karena adanya energi permukaan dan gaya tarik-menarik permukaan. 17 Jika zat yang diadsorsi merupakan elektrolit maka adsorpsi akan berjalan lebih cepat dan hasil adsorpsi lebih banyak jika dibandingkan dengan larutan non elektrolit, amoniak termasuk elektrolit. Hal ini disebabkan karena larutan elektrolit terionisasi sehingga didalam larutan terdapat ion-ion dengan muatan berlawanan yang menyebabkan gaya tarikmenarik Van der Waals semakin besar, berarti daya adsorpsi semakin besar. ${ }^{18}$ Ada beberapa faktor yang mempengaruhi daya serap adsorpsi, antara lain temperatur, $\mathrm{pH}$, dan waktu kontak. ${ }^{15}$ Berdasarkan hasil penelitian terjadi variasi nilai suhu pada setiap perlakuannya, akan tetapi masih dalam kisaran suhu untuk proses adsorpsi senyawa amoniak. Terjadinya fluktuasi suhu dalam limbah cair dipengaruhi lingkungan sekitar, diantaranya kelembaban udara dan suhu udara. Kenaikan suhu mengakibatkan kenaikan kapasitas adsorpsi dan laju adsorpsi. ${ }^{19}$ Dengan suhu yang sesuai dengan jenis sifat senyawa serapannya, maka proses adsorpsipun akan berjalan maksimal. Terjadi variasi nilai $\mathrm{pH}$ pada setiap perlakuan penelitian. Penurunan dan peningkatan $\mathrm{pH}$ dipengaruhi oleh berbagai waktu kontak karbon aktif pada setiap perlakuannya, karena nilai $\mathrm{pH}$ sangat mempengaruhi kondisi dari limbah cair rumah sakit itu sendiri, sebab amoniak merupakan senyawa organik dengan bentuk molekul ion nitrogen bermuatan negatif dan tiga ion hidrogen bermuatan positif. ${ }^{16}$ Untuk mencapai kenaikan persentase 
penurunan kadar amoniak dalam limbah cair rumah sakit diperlukan waktu kontak yang lebih lama. Hal ini terbukti, waktu kontak 120 menit dapat menurunkan kadar amoniak paling tinggi. Semakin turun kadar amoniak karena terjerapnya amoniak ke dalam rongga pori karbon aktif. Sehingga semakin lama waktu kontak akan terjadi deposit senyawa amoniak masuk ke pori-pori karbon aktif tersebut sampai terjadi kejenuhan. ${ }^{20}$ Kenaikan persentase penurunana kadar amoniak dalam limbah cair rumah sakit dipengaruhi suhu dan $\mathrm{pH}$ limbah cair itu sendiri. Semakin tinggi suhu maka proses adsorpsipun akan lambat. Nilai $\mathrm{pH}$ yang baik untuk proses adsorpsi harus berada pada nilai tertingginya atau sesuai dengan sifat serapan yang akan kontak dengan karbon aktif. Jika sifat senyawa asam maka proses adsorpsi akan berjalan maksimal pada $\mathrm{pH}$ asamnya, sebaliknya jika sifat serapan basa, maka proses adsorpsi akan berjalan maksimal pada $\mathrm{pH}$ basa. ${ }^{15}$

\section{SIMPULAN}

Berdasarkan hasil penelitian yang diperoleh, terdapat pengaruh variasi lama waktu kontak karbon aktif bijih plastik terhadap penurunan kadar amoniak limbah cair rumah sakit. Hasil yang diperoleh menunjukkan bahwa penurunan kadar amoniak pada limbah semakin menurun dengan makin lamanya limbah berkontak dengan karbon aktif bijih plastik. Besarnya efisiensi penyisihan kadar amoniak setelah perlakuan untuk waktu kontak 60 menit 18,40\%, 90 menit 35,07 \%, dan 120 menit 48,77 \%.Meskipun terjadi penurunan, secara substansi kadar amoniaktersebut masih di atas baku mutu, dimana Menurut Peraturan Menteri Lingkungan Hidup Republik Indonesia Nomor 5 tahun 2014 tentang Baku Mutu Air Limbah, kadar amoniak bagi usaha dan/atau fasilitas pelayanan kesehatan adalah sebesar $10 \mathrm{mg} / \mathrm{L}$.

\section{DAFTAR PUSTAKA}

1. Widayat W, Suprihatin S, Herlambang A. Penyisihan Amoniak Dalam Upaya Meningkatkan Kualitas Air Baku PDAM-IPA Bojong Renged Dengan Proses Biofiltrasi Menggunakan Media Plastik Tipe Sarang Tawon. Jurnal Air Indonesia 2010, 6(1):64-76. doi:10.29122/jai.v6i1.2456

2. Banon C, Suharto, Eka Totok. Adsorpsi Amoniak oleh Adsorben Zeolit Alam yang Diaktivasi dengan Larutan Amonium Nitrat. Jurnal Gradien 2008, 4(2):354-360.

3. Setyoningrum T.M., Setiawan A, Pamungkas G. Pembuatan Karbon Aktif Hasil Pirolisis dan Ban Bekas. Eksergi 2018, 15 (2) : 54-58. doi: 10.31315/e.v15i2.2387

4. Wanda. Upaya Indonesia Menanggulangi Sampah Plastik. JOM Fisip 2019, 6 (1) : 1-12.

5. Suprapto. Dampak Masalah Sampah terhadap Kesehatan Masyarakat. Jurnal Mutiara Kesehatan
Indonesia 2005, 1 (2) : 1-4. doi: 10.33485/jiikwk.v5i2.138

6. Wahyudi J, Prayitno H, Astuti AD. Pemanfaatan Limbah Plastik Sebagai Bahan Bakar Alternatif. Jurnal Libang 2018, 14 (1) : 58-67. doi: 10.33658/jl.v14i1.109

7. Sahwan FL, Martono Dj.H, Wahyono S, Wiyosodharmo LA. Sistem Pengelolaan limbah Plastik di Indonesia. Jurnal Teknik Lingkungan 2005, 6 (1) : 311-318.

8. Purwaningrum P. Upaya Mengurangi Timbulan Sampah Plastik di Lingkungan. Jurnal Teknik Lingkungan 2016, 8 (2) : 141-147. doi: 10.25105/urbanenvirotech.v8i2.1421

9. Cundari L, Yanti P, Syaputri K.A.. Pengolahan Limbah Cair Kain Jumputan Menggunakan Karbon Aktif dari Sampah Plastik. Jurnal Teknik Kimia 2016, 22 (3) : 26-33.

10. Budiyantoro, C. Thermoplastik dalam Industri. Surakarta : Teknika Media; 2010.

11. Kumar. A Review On Tertiary Recycling of High Density Polyethtlene to Fuel. Resources, Conservation, and Recycling 2011, 55 : 893-910.

12. Suharto, Ign. Limbah Kimia dalam Pencemaran Udara dan Air. Yogyakarta: CV.Andi Offset; 2011.

13. Syafalni S. Treatment of Dye Wastewater Using Granural Activated Carbon and Zeolite Filter. Jurnal Ilmu Aplikasi Modern 2012, 6 (2) : 37-51. doi: 10.5539/mas.v6n2p37

14. Wardhana IW, Siwi D, Ika D. Penggunaan Karbon Aktif dari Sampah Plastik untuk Menurunkan Kandungan Phosphat pada Limbah Cair. Jurnal Presipitasi 2013, 10 (1) : 30-40. doi: 10.14710/presipitasi.v10i1.30-40

15. Cecen, Ferhand. \& Ozgur, Aktas. Activated Carbon for Water and Wastewater Treatment. Canada : Jhon Wiley \& Sons; 2011.

16. Pujaatmaka, A. H. Kimia untuk Universitas. Jakarta: Erlangga; 1999.

17. Asip F, Mardhiah R, Husna H. Uji Efektifitas Cangkang Telur dalam Mengadsorpsi Ion Fe dengan Proses Batch. Jurnal Teknik Kimia 2008, $15(2): 22-26$.

18. Widayatno T. Adsorpi Logam Berat $(\mathrm{Pb})$ dari Limbah Cair dengan Adsorben Arang Bambu Aktif. Jurnal Teknologi Bahan Alam 2017, 1 (1) : 17-23.

19. Wirawan W, Masyithah Z, Leanon R. Pengaruh Suhu Adsorpsi dan Jumlah Penambahan Karbon Aktif terhadap Kecerahan Surfaktan Decyl Poliglikosida dari D-Glukosa dan Dekanol. Jurnal Teknik Kimia 2015, 4 (3) : 12-16. doi: 10.32734/jtk.v4i3.1475

20. Hamidi N, Wardana I, Widhiyanuriyawan D. Peningkatan Kualitas Bahan Baku Biogas Melalui Proses Pemurnian dengan Zeolit Alam. Jurnal Rekayasa Mesin 2011, 2 (3) : 227-231. 